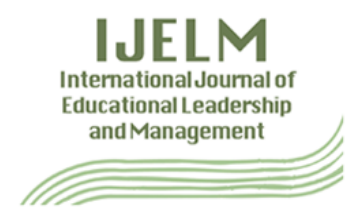

Instructions for authors, subscriptions and further details:

http://ijelm.hipatiapress.com

\title{
Leading and Teaching with Technology: School Principals' Perspective
}

Naciye Güliz Uğur \& Tuğba Koç ${ }^{1}$

1) Sakarya University, Turkey

Date of publication: January $16^{\text {th }}, 2019$

Edition period: January 2019 - July 2019

To cite this article: Uğur, N.G. \& Koç., T. (2019). Leading and Teaching with Technology: School Principals' Perspective. International Journal of Educational Leadership and Management, 7(1), 42-71.

DOI: $10.17583 /$ ijelm.2018.3758

To link this article: http://dx.doi.org/10.17583/ijelm.2019.3758

PLEASE SCROLL DOWN FOR ARTICLE

The terms and conditions of use are related to the Open Journal System and to Creative Commons Attribution License (CCAL). 


\title{
Leading and Teaching with Technology: School Principals' Perspective
}

Naciye Güliz Uğur

Sakarya University
Tuğba Koç

Sakarya University

\begin{abstract}
Technology has changed the way people live, from use of the Internet to the way they communicate with text messages and e-mails. This change is also evident in the education system. This study traced how principals' leadership roles have changed in the school setting because digital natives and society, in general, have become technologically savvy. The findings for this study were generated from interviews and observations of high school principals. This qualitative research study revealed that administrators are apprehensive about social media in the classroom and that they need to become more familiar with it to better implement technology effectively in the classroom. To ease their apprehension, principals need to change their ways of thinking about social media's use. Professional development in technology skills needs to be more available and flexible for principals to become a more visionary technology leader in the $21^{\text {st }}$ digital educational environment.
\end{abstract}

Keywords: Leadership, high school, educational technology, technology integration 


\section{Liderando y enseñando con tecnología: la perspectiva de los directores escolares}

Naciye Güliz Uğur

Sakarya University
Tuğba Koç

Sakarya University

\section{Resumen}

La tecnología ha cambiado la forma en que viven las personas, desde el uso de Internet hasta la forma en que se comunican con mensajes de texto y correos electrónicos. Este cambio también es evidente en el sistema educativo. Este estudio rastreó cómo los roles de liderazgo de los directores han cambiado en el entorno escolar porque los nativos digitales y la sociedad en general se han convertido en expertos tecnológicamente. Los hallazgos para este estudio se generaron a partir de entrevistas y observaciones de directores de escuelas secundarias. Este estudio de investigación cualitativa reveló que los directores tienen miedo de las redes sociales en el aula y que necesitan familiarizarse con ellas para implementar mejor la tecnología de manera efectiva en el aula. Para aliviar su temor, los directores deben cambiar sus formas de pensar sobre el uso de las redes sociales. El desarrollo profesional en habilidades tecnológicas debe ser más accesible y flexible para que los directores se conviertan en líderes de tecnología más visionarios en el entorno educativo digital del siglo 21.

Palabras claves: Liderazgo, Educación Secundaria, Tecnología educativa, Integración tecnológica.

2019 HipatiaPress

ISSN: 2014-9018

DOI: $10.17583 /$ ijelm.2019.3758
Hipatia Press www.hipatiapress.com 



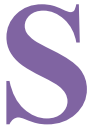
chool administrators today face a different set of challenges than their predecessors. Over the years, computers were put in high schools and elementary schools, as well as in central administrative offices.

Literature suggests that one of the major challenges is infusing technology into the curriculum. Principals who can carry out technology implementations in their schools should behave as technology leaders (Demski, 2012). Education is an area where technology can enhance the overall experience for teachers and students, and society is embracing this idea (Flemmer, 2007). In fact, one of the most powerful factors in increasing the use of technology in teaching, learning, and student achievement is societal pressure on administrators to use technology as an implementation tool ( $\mathrm{O}^{\prime} \mathrm{Dwyer}$, Russell, \& Bebell, 2004). Because they have little experience with new technology, however, very few school administrators claim to be technology experts, yet in the $21^{\text {st }}$ century technology is in every field of education (Gosmire \& Grady, 2007)

Dias (2001) believes it is important for school administrators and others in leadership roles to understand what constitutes best practices in technology integration. While principals may be willing to implement technology, they need more custom professional development to help them move to effective implementation (Papaioannou \& Charalambous, 2011). As instructional leaders of the building, principals who do not understand how to use technology cannot properly evaluate the use of it by teachers for instruction and students for achievement.

As technology evolves, administrator skill sets must change to remain current (Jerald, 2009). Studies have shown that administrative support is significant to the implementation of technology in schools (Gibson, 2001; Kincaid \& Felder, 2002; Shoffner, 2001). Research indicates that school administrators should play a critical role in the successful integration of technology in their schools (Twomey, Schamburg, \& Zieger, 2006). Today, principals should have a clear vision of their role in technology integration and implementation because it is an essential function of their duties as instructional leaders. However, the problem is that principals may not 
understand their role in implementing the technology. Some lack the necessary skills and knowledge to effectively function as technology leaders. According to Townsend (1999), principals need to reclaim their roles as educational leaders in technology. Maintaining a firm leadership role in technology would help administrators keep their schools current (Jerald, 2009).

The old-fashioned classroom atmosphere is becoming obsolete with the onset of virtual classrooms or schools. Students can be taught by someone in another country by teleconference, eBooks are replacing textbooks, and texting is producing another set of vocabulary in this global society (BrooksYoung, 2010). Technology skills are required of school administrators in order for them to lead in a technology-rich educational environment. One of the major reasons for the lack of technology development for principals has been the struggle to identify the administrator knowledge base needed in technology and the management of technology in the school situation (Awalt \& Jolly, 1999). In their study, Gürfidan and Koç (2016) also investigated the relationship between school culture, technology leadership and support services on teachers' technology integration. The results of the study revealed that a positive school climate can result in effective leadership behaviors and adequate support and encouragement for the increased use of technology.

This study looked at high school administrators and discussed their mission and vision of technology in their schools and how technology changed over the years. It addressed the attitudes and perceptions surrounding the use of technology in the classroom and its implementation as an instructional tool.

\section{Theoretical Framework}

Technology Standards for School Administrators (TSSA Collaborative, 2001) relates to the standards created by the International Society for Technology and Education (ISTE, 2006). TSSA was implemented in 2001 by the TSSA Collaborative. The ISTE is an organization committed to promoting the educational curriculum of technology to improve learning and support 
teaching with technology. ISTE writes standards and guidelines for administrators, teachers, and students in technology. The ISTE standards are representations to inform educational stakeholders of what indicates effective school leadership for comprehensive and effective use of technology in the schools (ISTE, 2006; Twomey, et al., 2006). The 2009 ISTE theoretical framework is based upon the premise that our educational system is attempting to keep pace with the impact computers are making in society. These international standards are used to reform school improvement (ISTE, 2006; Twomey, et al., 2006). The ISTE 2009 standards are:
$>$ Visionary leadership
$>$ Digital age learning culture
$>$ Excellence in professional practice
$>$ Systemic improvement
$>$ Digital citizenship

In the 21 st century, principals focus on implementing technology in the school buildings. A principal in the information digital age is an instructional leader, a visionary leader, and able to use technology for management. However, principals may not fully understand their roles and the expectations for successful integration of technology in their schools. Davis (2008) suggested that although most have had training in technology, many school principals are not comfortable with technology or knowledgeable enough about technology integration techniques. Because principal training programs normally do not focus on the skills about technology, administrators should refocus their Professional development programs. Administrative training courses are not teaching school principals or central office administrators how to use technology effectively. Despres (2011) suggested education and training for administrators were somewhat inadequate because they did not prepare administrators to meet these standards. Many school administrators received their degrees before computer technology made its impact, and many colleges and universities do not have up-to-date courses that cover the scope of administrative functions that can be managed by computers (Richardson, Flora, \& Bathon, 2012). 
Though this is the age of modern technology, there is little research available on how high school principals use technology in their buildings. Tweed (2013) undertook a quantitative study that refers to the implementation of new technologies in the classroom. The study also focused on the age of the teacher, years of teaching experience, quality of professional development, and teacher self-efficacy as defined by Bandura (1997) to examine the manner in which these factors relate to implementing new technologies in the classroom. Participants indicated that technology had at least somewhat impacted the way they teach in their classrooms and findings indicated that the self-efficacy of a teacher is significantly positively related to classroom technology use of teachers.

Hughes and Zachariah (2001) conducted a study to ascertain what leadership attributes affect the integration of technology to improve teaching and learning. The research focused on the relationship and how it is affected as roles and responsibilities shift. A principal's leadership style affected the implementation of technology in a school. Facilitative leadership by the principal was seen by teachers as the key to successful technology implementation (Baylor \& Ritchie, 2002; Hasselbring et al., 2000; Hughes \& Zachariah, 2001). Administrators who promote technology as a tool for collaboration and stimulation for authentic learning experiences can allow for far greater student achievement than ever before (Hughes \& Zachariah, 2001).

Anderson and Dexter (2005) provided a narrative of a national survey that capitalizes on school leadership in technology implementation. The findings suggest that although technology infrastructure is important, technology leadership is necessary for effective utilization of technology in schooling. For school administrators to provide effective leadership in their schools in the 21 st century, they must possess knowledge and understanding of the issues and the capabilities of technology. They must use technology appropriately in the fulfilment of their roles of coordinator and communicator of school programs and activities (Richardson \& McLeod, 2011). Akbaba-Altun (2004) conducted a study in a small city west of Turkey that explored how elementary school principals' roles related to information technology classrooms and how school principals perceived their roles and what is expected in the school. 
This study ties back to technology leadership, implementation, and systemic planning in an education setting. Serhan (2007) stated that school principals as technology leaders are required to have a long-term vision and commitment to coordinating and allocating required resources for the school. Serhan's study focused on principals' attitudes toward the use of technology. Results of this study revealed that principals had positive attitudes toward the use of technology in their schools. If principals are comfortable with using technology, they will enforce the new equipment in their schools. In McKinley's (2014) study, he stated that Banuglu (2011) studied the leadership skills of secondary education principals and their ability to coordinate technology integration throughout a school system. The findings show that principals, both male and female, have performed considerably well in technology leadership proficiency and positive perception of technology use in instruction. Banuglu stated that many principals perform at the expectation level of professional development trainers.

Schools and universities were not responding in the recent years fast enough to the need to include technology in educational leadership programs (Dikkers, Hughes, \& McLeod, 2005; Hughes et al., 2001). However, if technology can be integrated into this professional preparation programs, including formal degree coursework as well as in-service seminars, which develop the perspectives and skills necessary for this bottom-up reporting so that it will occur accurately with efficiency and with fidelity (Professional Development, 2011).

McLeod, Logan, and Allen (2002) conducted a study of educational leadership programs that prepare school administrators to use and enhance the use of information technology. They discovered that it is important for educational leadership programs to prepare future school administrators to facilitate effective technology integration in their schools. School administrators often lack vital knowledge of technology trends, issues, and skills; therefore, they are not effective leaders of technology management. A Saskatchewan-based research project entitled Beyond the Mouse and Modem (Henderson, James, \& Cannon, 2003) surveyed over 2,000 Saskatchewan teachers about their knowledge and use of technology in the classroom. 
The survey revealed that teachers lacked the skill and knowledge levels needed for effective implementation. To better enhance learning outcomes, teachers needed to go beyond basic technologies and advance toward highyield technology integration strategies. In Smith's (2011) correlational research, he focused on the effective use of technology in the classroom and the instructional technology leadership of the school principal. The results indicated a correlation existed among the variables for both principals and teachers for instructional technology/skills and support actions of the principal and effective use of technology in the classroom. There was a positive correlation in the effective use of technology in the classroom.

Bailey (2000) stated the essential elements for understanding technology integration and leadership in the 21 st century. Bailey stated what technology leaders need to know concerning technology integration, such as change, curriculum, ethics, infrastructure, safety and security, staff development, teaching/learning, technology planning, technical support, and technology leadership. The combination of curriculum and technology is crucial in terms of creating a superb teaching and learning environment. In fact, the integration of new technological developments into education should enable students to make use of new technologies just as easily as they make use of technology like books, maps, and pencils (Cakir and Yildirim, 2009; Hew and Brush, 2007). Researchers emphasise the importance of having a sufficient number of computer teachers who embrace their profession and communicate well with other teachers (Cakir 2008; Goktas and Topu, 2012; Seferoglu, 2007), as well as the key role administrators play in the integration of technology in the schools (Afshari et al., 2008; Brockmeier et al., 2005; Kearsley and Lynch, 1992; Seferoglu, 2009).

Slowinski (2003) stated, "administrators who implement technology effectively in their schools and communities will contribute greatly to both education and the economy in the 21st century" (p. 25). A strong link between educational technology and school leadership is necessary to support improvements in education. The expansion and growth of technology use in school have changed the responsibility and role of the principals to implement advanced, enriched curriculum integration and to be able to lead faculty and 
students. Principals think of technology as an essential tool for changing the way teachers teach and the way students learn (Moeller \& Reitzes, 2011). However, the dichotomy is that these principals lack the understanding of how technology should be integrated into the learning environment (Slowinski, 2003). Among the challenges of technology leadership was the number of people that need to be involved in learning how to use technology, the lightening-fast speed in which technology continued to evolve, and the development of how technology was being used for educational purposes (Creighton, 2003). Daniel and Nance (2002) propose that school administrators should have some level of participation at all levels of the policy enterprise since it is they who will be ultimately responsible for the implementation and success of any school-related technology endeavor.

For implementing technology in schools, the Technology Standards for School Administrators are indicators of effective leadership and can be used to guide the redesign and/or development of new graduate courses for school administration programs (Ertmer et al., 2002). Daniel and Nance (2002) examine the irony of state lawmakers and how they have not determined a role for administrators in educational technology. While creating laws for the use of educational technology, lawmakers failed to define a role for the administration who must implement it. Meanwhile, administrators in their leadership roles are ultimately held responsible for the teaching and learning process that occurs in schools (Daniel \& Nance, 2002, p. 211).

Ury's (2003) dissertation study was undertaken in the state of Missouri with the public school districts. This study was on the school principals' computer usage and conformity to technology standards. The purpose of Ury's study was to design a reliable and valid survey instrument that could be used to determine school principals' level of computer usage and performance. The findings of the sample had a $94 \%$ confidence level of the population. Ury (2003) developed the Survey of Technology Standards for School Administrators (STSSA). The survey focused on computer skills in the area of technology integration. There was a need to integrate educational technology into the schools with the school principal's leadership. His results 
show that the STSSA can reliably measure public school principals' perceived use of computers and performance.

\section{Purpose and Significance of the Study}

This study explored the attitudes and perceptions related to how high school administrators supported their technology mission and vision by investigating how they organized, planned, and implemented the technology. There is a plethora of research suggesting advancement in the use of technology for teachers and students (Thacker, 2007), but research pertaining to the perceptions of administrators has been lacking. Furthermore, because administrators are leaders of the educational system, it is important to look at their knowledge bases and uses of technology as their perceptions and usage are indicative of their vision, organization, and planning.

More studies are needed on secondary school principals and their role, vision, and professional development as technology leaders. Studies like mine are needed for administrators to lead in a technology-rich educational environment. This study is based on creating a principal's knowledge base to help principals' lead to effective implementation in their schools. Background factors for principals such as age, years of experience, and access to technology were not significant in their instructional technology leadership ability to promote the effective use of technology in the classroom. The lack of high-quality research on school technology leadership reinforces the need for this study. It provides a foundation for this phenomenological study grounded in school administrative technology leadership research. This research study may help inform and direct further studies in technology leadership and educational leadership programs. The literature describes how school administrators' technology leadership roles have changed since the inception of technology in schools. The findings are needed for professional development opportunities that engage administrators on how to lead technology within their schools. 


\section{Methodology}

It is suggested that principals have a vision concerning the implementation of technology in order to become more effective instructional leaders (McLeod, Logan, \& Allen, 2002). This vision must communicate the commitment of principals to the effective use of technology. The focus of this study was to investigate how high school principals' attitudes enabled them to effectively organize, utilize, and implement the technology.

Research Questions

1) What are the principals' attitudes toward technology use?

2) How do principals describe their support of teachers in the use of technology?

This research provides a detailed description, an analysis of the themes or issues, and the researcher's interpretations or assertions about the study. These interpretations may be called "lessons learned" (Guba \& Lincoln, 1989). This study focused on the qualitative approach of principals' attitude towards technology practices in high schools and their effects on leadership. The trustworthiness was based on the information received from the participants, persistent engagement, prolonged engagement, peer debriefing, member checks, triangulation, and an audit trail. The qualitative study consisted of interviews with 10 high school principals.

A 16-item interview protocol using semi-structured questions was used. The interview protocol was divided into five sections: visionary leadership, digital age learning culture, excellence in professional practice, systemic improvement, and digital citizenship.

Visionary leadership included five questions addressing the mission and vision of the school in implementing the technology. Digital age learning culture included three questions addressing how technology has changed for 


\section{4 Ŭgur \& Koç - Leading and Teaching with Technology}

the 21 st century. Excellence in professional practice addressed two questions that involved curriculum integration in your school. Systemic improvement included two questions addressing the infrastructure and hiring in technology. And lastly, digital citizenship addressed four questions dealing with policies, procedures, legislation laws, professional development, and personal beliefs about technology. The researchers set up interviews with all participants by telephone and e-mail. The researchers visited with all participants personally to interview them.

The participants were administrators from Sakarya, İzmit and İstanbul schools. From these regions, 10 high schools with grade levels 9 through 12 were selected. The school sizes ranged from medium to large enrolments. A majority of the participants had been a high school principal for more than 10 years. These urban principals were purposefully selected because of their experience, diversity, and knowledge about the use of technology in high school settings dealing with the policies. Purposeful sampling in selecting participants is common in qualitative studies. This was a strategy to choose small groups or individuals likely knowledgeable and informative about the phenomenon of interest and selection of cases without needing or desiring to generalize to all such cases (McMillan \& Schumacher, 2001).

In qualitative studies, the researcher is the primary instrument for data analysis and data collection (Marshall \& Rossman, 1999). As such, our role as the researcher was to be the interviewer. We used research questions and an observational protocol to take notes as the participant was being interviewed. We conducted one-on-one interviews with each high school building principal to acquire information about their experiences with technology implementation. 


\section{Results}

The researcher selects particular elements from the population that will be representative or informative about the topic of interest. For example, in research on principal technology leadership, it may be most informative to observe expert principals rather than a sample of all vice principals and principals. Purposeful sampling provided rich information from participants that explained the phenomenon through the voice of those who knew it best. The participant demographics are located in Table 1.

\section{Table 1}

Summary of Participants by Demographics

\begin{tabular}{lllll} 
Principal & Gender & Age & Grades & School Size \\
\hline A.1 & Female & 58 & $9-12$ & 2,404 \\
B.2 & Female & 45 & $9-12$ & 1,392 \\
C.3 & Female & 59 & $9-12$ & 968 \\
D.4 & Male & 46 & $9-12$ & 840 \\
E.5 & Male & 57 & $9-12$ & 1,137 \\
F.6 & Male & 50 & $9-12$ & 1,269 \\
G.7 & Female & 40 & $9-12$ & 500 \\
H.8 & Male & 50 & $9-12$ & 965 \\
I.9 & Male & 64 & $9-12$ & 900 \\
J.10 & Male & 62 & $9-12$ & 941
\end{tabular}

Principal A has been in education for 19 years and served as an administrator for 12 years, including 8 years as a high school principal, 4 years as a middle school principal, and 7 years as a high school vice principal.

Principal B has been in education for 21 years. This principal has served as an administrator for 16 and a half years, which includes 14 years as a vice principal and 2 and a half years as a principal.

Principal $\mathrm{C}$ has served as an administrator for 27 years, which includes 5 years as a vice principal and 22 years as a principal. She has been in education for 35 years. 
Principal D has served as an administrator for 11 years as a high school principal for only 1year, middle school principal for 7 years, vice principal for 2 years, and curriculum coordinator/vice principal for 1 year. He has been in education for 21 years.

Principal E has served as an administrator for 28 years; currently, he is in his first year as a high school principal. Principal E has held several administrative positions, which includes 24 years as a high school vice principal, 2 years as a junior high school principal, and 2 years as a middle school vice principal. Principal E has been in education for 32 years.

Principal F became a high school administrator fifteen years ago. He spent 10 years as a high school vice principal, 4 years as a junior high principal, and is currently in his first year as a high school principal. He has been in education for 25 years.

Principal $\mathrm{G}$ has served as an administrator for 9 years; during 8 of those years, she was a high school vice principal. Currently, she is in her first year as a high school principal, and she has been in education for 20 years.

Principal $\mathrm{H}$ has been in education for 25 years and has served as an administrator for 12 years. Principal $\mathrm{H}$ has served 3 years as an elementary school vice principal, 3 years as a middle school principal, and is currently in his sixth year as a high school principal.

Principal I has been in education for 34 years. This principal has served as an administrator for 17 years, as a high school vice principal for 16 years and is currently in his first year as a high school principal.

Principal $\mathrm{J}$ has been in education for 39 years and has served as an administrator for 19 of those years. 


\section{Data Collection}

Before any interviews were conducted, all 10 principals were given an informed consent form that outlined their rights and responsibilities as participants in this study. They were asked to sign the informed consent document before the interviews began. Semi-structured interviews were conducted with each urban high school administrator on his or her campus in order to collect data for this study. Each participant in the study was asked a set of questions about his or her background and personal experience utilizing technology. An interview protocol was used to guide the interview process. The interview questions were based upon the Technology Standards for School Administrators/International Society for Technology in Education Performance Indicators and Technology Standards for School Administrator Collaborative.

The purpose of this study was to investigate how high school principals' attitudes enabled them to effectively organize, utilize, and implement the technology. This qualitative study will also discover principals' attitudes toward technology use as well as whether administrators support teachers in their use of technology.

The main audience for this case study was principals, superintendents, technology directors, and policymakers. Principals are target audience members as the findings will inform their practice to allow enhancements and revisions surrounding their technology use and support and encouragement of staff technology use.

School 1 is identified as Principal A.1, School 2 as Principal B.2, School 3 as Principal C.3, School 4 as Principal D.4, School 5 as Principal E.5, School 6 as Principal F.6, School 7 as Principal G.7, School 8 as Principal H.8, School 9 as Principal I.9, and School 10 as Principal J.10. The letter represents the order in which the participants were interviewed. The number following the letter was randomly assigned and indicates the number of participants in the study. 
This study consisted of 10 participants. The participants worked in three urban school districts where they led large high schools. The participants were experienced educators with years in education ranging from 18 to 39. All served as vice principals before assuming the role of principal.

The findings for this study were generated from interviews and observations. The notes were reviewed to search for common patterns. Open coding was used to recognize concepts in the phrases and words, and axial coding then linked the open codes. The four axial codes are listed below.

$>$ Technology/Professional Development

$>$ Principals

$>$ Teachers

$>$ Students

During the process of open coding, the data were read multiple times and grouped by phrases and words and open codes were written on different coloured index cards. Axial codes or major themes emerged from the open codes. Axial codes linked the open codes by relationships, which eventually revealed themes.

\section{Technology/Professional Development}

All principal participants believed that professional development in technology was extremely important in their buildings. They felt that principals should participate in technology professional development to stay informed and to lead their schools. Five of the principals discussed their need for professional development in technology.

All participant principals wanted their teachers in the building to check their e-mails, and professional development in technology would allow them to do that. While the principals felt they were receiving technology professional development hours, three of them thought teachers were not taking a vast amount of hours. Principal E.5 noted, "I strongly encourage teachers to use technology." Two principals think that teachers do not take 
advantage of online Professional development because they are only worried about getting required and recommended hours.

Receiving professional development in technology was important to principals. Principals believed it was important for them to participate in professional development in technology in order to lead in their schools. The majority of the principals had completed a large number of computer training and felt they needed to stay abreast of technology. In general, all principals wanted their teachers to know the basics of technology. Some principals encouraged their teachers to take more technology professional development for communication purposes and to stay abreast of technological changes. All principals were aware of the need to stay ahead of the digital age of technology.

\section{Principals}

These principals of the information age wanted teachers to be more helpful and effective in technology so students could get the technology instruction they needed in the 21 st century. Principal B.2 noted, "a lot of teachers are still stuck in the same way; some teachers do not want to change; some teachers feel intimidated." One principal uses technology in all his faculty meetings to encourage teachers to integrate and implement technology in the classroom. One principal stated he wanted his vice principals and staff to become paperless by using e-mail to communicate, send lesson plans, and share resources. The teacher lesson plans are e-mailed by a computer to administrators. Some teachers and principals were resistant to change and technology was intimidating. Principal I.9 commented, "I don't have time to really use the computer at work."

All principals had a mission and vision for their technology leadership. One principal's vision was to have the most up-to-date technology available for teachers in the building. Several of the principals discussed the demonstration of leadership in the advancement of technology and focused on becoming familiar with how to use it in administration. One principal commented on how technology changed the operation of the school. This 
principal's vision was to use more technology and less paper to communicate. Principal E.5 noted that "I strongly encourage teachers to use technology."

The attitudes of school principals dealing with new technologies in professional development will persuade, promote, and support teachers as they engage in new learning opportunities. The principals are the ones that set the tone by using technology in presentations, and, daily work. If the leader of the building has a mission and vision and is using technology, it will encourage teachers to make a change and embrace it. The principals should attend technology in-service sessions with teachers in their building. The principals are able to collaborate with other administrators on their technical reports and data.

\section{Teachers}

Participants wanted to help all teachers feel comfortable with technology use in the classroom. All the principals supported the effective use of technology and their teachers. The principals explained the effective use of technology as using it across all facets of teaching and learning. In order to support the effective use of technology, the principals stated that they provided equipment, software, and hardware for the classrooms.

The principals commented on social networking in the schools. This was a hot topic for some principals; they expressed negative attitudes toward social networking because it brought on unnecessary conflict among students. However, other principals thought that social networking has a place in the classroom. Principal F.6 noted, "I think nothing of it." Some teachers create Blogs. Five of the principals had a concern with social networking and how it fit into the curriculum, as well as how it keeps students safe.

Some teachers like to utilize new technology tools and incorporate new ways of integrating technology into the curriculum. Some teachers used Facebook for project-based assignments or homework. The students can learn how to use the software in an academic setting and be held accountable for 
their actions. Teachers are encouraged by the principals to share lessons by email or Web-pages that have been set up. Teachers should be able to choose the technology professional development that interests them along with what is best for the academic setting.

\section{Students}

The principal participants described the digital divide as a split between students who were being raised in a technology-driven society and the technology-challenged teachers who teach them. Three principals said that students need to be college ready. They felt being college ready includes giving students the opportunity to learn about technology from teachers who have been taught how to use and teach with computers, iPads, the Internet, and other forms of technology. Principal H.8 noted, "all students are college ready and all students entering colleges will have to be computer literate."

Several of the principals know that iPads are very popular among adults and students. A couple of the principals talked about smartphones, mobile phone applications, and e-readers, for reading books and calculating math problems. One principal talked about teaching students to apply content into using YouTube. The principal participants wanted more training and teaching opportunities for their teachers to help them narrow the divide.

Social media for students is very popular but a lot of issues comes from not being able to use it in some of the schools. Most schools had social media blocked, and the students used their cell phones to access it during the school hours. There should be educational in-services for teachers to learn the proper way to use these platforms. The teacher is able to integrate the social media into the curriculum and the student learns first-hand how to use the program without any penalties. Social media plays a big role in our society today. Social media can lead to students sharing misinformation, downloading websites that have been blocked, and videoing at inopportune times. If students are taught social media skills in schools by a trained professional they would have some knowledge of the dos and don'ts. 
Technology for students is a necessity in the home, school, office, and society. Students are able to download their data assessment results from the computer. Technology is a chance for students to learn and gain skills that will benefit them in their careers and in their jobs. The teacher uses strategies for the computer skills in all subject areas to give a better chance for all students to succeed in the digital age. Students are able to take web-based classes, marketing classes, career life skills, and business classes that will help them in the future.

\section{Conclusion}

The interviews revealed that most principals were comfortable with using and implementing the technology. The observations revealed that most of the principals were comfortable in their level of expertise in technology, and three principals were able to share stories of teachers with success in technology. One principal was able to address problems that arose with the uses of technology in administrative and classroom use. Eight of the 10 principals were able to demonstrate support and leadership of technology professional development use. The principals generally believe that technology needed to be implemented in the curriculum for the students and the ever-changing technological society, however only the three of the principals understood the implications of planning, infrastructure, and budgeting of technology.

This analysis consists of themes that emerged from the data. The first selective code to emerge in the study was "leadership". Leadership was supported by three open codes: (a) principals, (b) professional development, and (c) technology coordinators. Principals are instructional leaders as well as an administrator in the school building. As such, their attitude determines the mood of the faculty, staff, and students. It can persuade teachers to embed technology use in their lesson planning and promote technology use among students through electronic interactions. As the leader of the building, the principal can foster a culture of technology use among teachers and students that support aggressive use of technology within and between school, community, and home by way of presentations, evaluations of programs, and teaching. 
The second theme to emerge in the study was information opportunities. Information opportunities were based on the following: (a) technology and (b) teachers. Instructional and ongoing professional development training is vital in this age of technology. It is important that the community know what is going on inside the schools to help with modifying the educational wants and needs of performing at the highest caliber. The teachers learn various strategies of teaching methods and stay updated with the integration of technology.

The third theme to emerge in the study was the community. The community was supported by the following: (a) students and (b) parents. Students and teachers interact using various technology tools in the classroom, but their interaction can expand to the parents and the community. Interaction with technology must expand beyond school walls to foster communication among all stakeholders. The students need equal access in school and at home working with technology. We want our students to be successful, wellrounded, and able to graduate from high school. Access to technology outside of school can help our students connect and communicate with the community around them. Principal A.1 noted, "easily accessible for all parents and keep the lines of communication open. Every person should have equal access so he/she can be the best for all children."

This study sought to explore the attitude of principals toward technology and their support of teachers and teachers' use of technology. The goal was to determine whether principals actually support, promote, and encourage technology use in their buildings and whether they modeled technology use to foster teacher technology use throughout the curriculum. This study helped determine how administrators can facilitate the integration of technology in the classroom.

Three theories emerged from the data which provide insight on how principals are implementing technology in an instructional environment to communicate with teachers and students: (a) leadership, (b) information opportunities, and (c) community. These theories were supported by axial codes and open codes. Collected data were triangulated using interviews, 
observations, and field notes. Research associated with the two research questions for this study was limited.

Research Question 1 was: What are the principals' attitudes toward technology use? This study showed that while some principals were confident with their abilities to implement the mission and vision for technology in their schools, others were not so knowledgeable about their roles. They believed that a variety of factors hindered their implementation, from the lack of proper professional development to the lack of funding for instructional materials, software, and hardware. Also, a lack of time management for learning the technology practices was a big issue for principals.

Research Question 2 was: How do principals describe their support of teachers in the use of technology? This study showed most principals felt teachers did not have enough technology professional development nor did they take full advantage of the professional development offered. The principals stated the teachers were not trained on proper implementation of technology equipment or technology integrated lesson plans to help them integrate technology in the classroom. Higher education programs were not training principals and teachers on how to use technology as an instructional tool. They need to attend professional development that aligns with their interest in technology that way the comfort level should increase.

Technology has changed the way people live, from use of the Internet to the way we communicate with text messages and e-mails. This change is also evident in our school system. This study traced how principals' leadership roles have changed in the school setting because digital natives and society, in general, have become technologically savvy. The findings for this study were generated from interviews and observations of high school principals.

This qualitative research reveals that principals must be leaders of technology in their mission and vision for their schools. They must get involved with planning and infrastructure to ensure their schools are properly equipped with technology tools. Teachers will be better equipped to incorporate technology in the classroom if they have adequate access as well 
as proper professional development. Students will be better able to compete in the digital age of the 21 st century. This study calls for school administrators to be held accountable for the integration of technology into the curriculum at their school.

The implications from this study could prompt further research in a variety of areas pertaining to technology. A specific area to consider would be more research studies on secondary high school principals' technology leadership attitudes and behaviors as they relate to the community. Further research on educational technology leadership in the community is promising because it incorporates the stakeholders who also represent the community.

\section{References}

Afshari, M., Bakar, K. A., Luan, W. S., Samah, B. A., \& Fooi, F. S. (2008). School leadership and information and communication technology. The Turkish Online Journal of Educational Technology, 7(4), 82-91.

Akbaba-Altun, S. (2004). Information technology classrooms and elementary school principals' roles: Turkish experience. Education \& Information Technologies, 9(3), 255-270.

Anderson, R., \& Dexter, S. (2005). School technology leadership: An empirical investigation of prevalence and effect. Educational Administration Quarterly, 41(1), 49-82.

Awalt, C., \& Jolly, D. (1999). An inch deep and a mile wide: electronic tools for savvy administrators. Educational Technology and Society 2(3).

Bailey, G. D. (2000). Technology leadership: Ten essential buttons for understanding technology integration in the 21 st century. Technology 
66 Ŭgur \& Koç - Leading and Teaching with Technology

Leadership Center. Retrieved from http://coe.ksu.edu/bailey/currentbuttonart.html

Bandura, A. (1997). Self-efficacy: The exercise of control. New York, NY: W.H. Freeman.

Banuglu, K. (2011). School principals' technology leadership competency and technology coordinatorship. Educational Sciences: Theory and Practice, 11(1), 208-213.

Baylor, A., \& Ritchie, D. (2002). What factors facilitate teacher skill, teacher morale, and perceived student learning in technology-using classrooms? Computers \& Education, 39(4), 395-414.

Brockmeier,J. M. \& Hope, W. C. (2005). Principals' relationship with computer technology. NASSP Bulletin 89(2), 45-63.

Brooks-Young, S. (2010). Teaching with the tools kids really use: Learning with web and mobile technologies. Corwin Press.

Cakir, R. \& Yildirim, S. (2009). What do computer teachers think about the factors affecting technology in schools? Ilkogretium Online, 8(3), 952964.

Cakir, R. (2008). Preservice and in-service basic education computer teachers' Professional growth in terms of perceptions of teaching, pedagogical competencies and subject matter knowledge. Unpublished doctoral dissertation, METU, Ankara.

Creighton, T. (2003). The principal as technology leader. Thousand Oaks, CA: Corwin Press.

Daniel, P. T. K., \& Nance, J. P. (2002). The role of the administrator in instructional technology policy. B.Y.U. Education and Law Journal, 211 231.

Davis, M. (2008, Winter). The knowledge gap. Digital Directions, 1(3), $15-$ 17.

Demski, J. (2012). 7 Habits of highly effective tech-leading principals. The Journal. Retrieved from http://thejournal.com/articles/2012/06/07/7habit 
Despres, B. (2011). Technology education issue in British Columbia. The University of British Columbia Okanagan. Kelowna, BC VIV IV7

Dias, L. B. (2001). Technology integration: Best practices-Where do teachers stand? International Electronic Journal for Leadership in Learning.

Dikkers, A. G., Hughes, J. E., \& McLeod, S. (2005). A bridge to success: STLI. In that no man's land between school technology and effective leadership, the University of Minnesota's School Technology Leadership Initiative is a welcoming bridge. T.H.E. Journal, 32(11), 20.

Ertmer, P. A., Bai, H., Dong, C., Khalil, M., Park, S. H., \& Wang, L. (2002). Online professional development: Building administrators' capacity for technology leadership. Paper presented at the National Educational Computing Conference Proceedings, San Antonio, TX. Journal of Computing in Teacher Education, 19(1), 5-11.

Flemmer, C. (2007). The positive impact of technology on teaching and learning. Boise State University.

Gibson, I. W. (2001). The role of school administrators in the process of effectively integrating educational technology into school learning environments: New research from the mid-west. Paper presented at the Society for Information Technology and Teacher Education International Conference, Orlando FL.

Goktas, Y. \& Topu, B. (2012). ICT teachers' assigned roles and expectations from them, Educational Sciences: Theory and Practice, 12(1), 473-478. Retrieved from http://ocw.metu.edu.tr

Gosmire, D., \& Grady, M. L. (2007). A bumpy road: Principal as technology leader. Principal Leadership, 7(6), p. 15-21). National Association of Secondary Principals. Reston, VA.

Guba, E. G., \& Lincoln, Y. S. (1989). Fourth generation evaluation. Beverly Hills, CA: Sage Publications, Inc.

Gürfidan, H., \& Koç, M. (2016). The Impact of School Culture, Technology Leadership, and Support Services on Teachers' Technology Integration: A Structural Equation Modeling. Education and Science, 41(188), 99116. 
Hasselbring, T. S., Smith, L., Glaser, C. W., Barron, L., Risko, V. J., Snyder, C., Rakestraw, J., \& Camobell, M. (2000). Literature review: Technology to support teacher development. Washington, DC: Office of Educational Research and Improvement. (ERIC Document Reproduction Service No. ED 448159).

Henderson, K. S., James, W., \& Cannon, R. (2003). Beyond the mouse and modem: teacher technology implementation in Saskatchewan. Dr. Stirling McDowell Foundation for Research into Teaching Inc.

Hew, K. F., \& Brush, T. (2007). Integrating technology in K-12 teaching and learning: Current knowledge gaps and recommendations for future research. Educational Technology, Research and Development, 55(3), 223-252. doi:101007/S11423-006-9022

Hughes, M., \& Zachariah, S. (2001). An investigation into the relationship between effective administrative leadership styles and the use of technology [Abstract]. International Electronic Journal for Leadership in Learning, 5(5).

ISTE: National educational technology standards [NETS-A] and performance indicators for administrators, (2006). Eugene, OR: International Society for Technology in Education. Retrieved from http://www.iste.org

Jerald, C. D. (2009). Defining a 21 st century education. The Center for Public Education.

Retrieved

from

http://www.centerforpubliceducation.org/LearnAbout/gmnode/270.aspx

Kearsley, G. \& Lynch, W. (1992). Leadership in the age of technology: The new skills. Journal of Research on Computing in Education, 25(1), 5060 .

Kincaid, T., \& Felder, I. (2002). Leadership for technology integration: the role of principals and mentors. Educational Technology \& Society, 5(1).

Marshall, C., \& Rossman, G. (1999). Designing Qualitative Research (3rd ed.). London: Sage Publications. 
McKinley, B. M. (2014). The relationship of faculty demographics and attitudes toward technology integration. (Doctoral Dissertation). Retrieved from ProQuest Dissertation and Theses.

McLeod, S., Logan, J. \& Allen, J. (2002). Preparing school administrators to use and facilitate the use of information technology: A study of educational leadership programs. Paper presented at the American Educational Research Association (AERA) 2002 Annual Meeting, New Orleans, LA.

McMillan, J., \& Schumacher, S. (2001). Research in Education. A Conceptual Introduction. New York: Longman.

Moeller, B. \& Reitzes, T. (2011). Integrating technology with studentcentered learning. Quincy, MA: Nellie Mae Education Foundation. Retrieved from http://www.nmefdn.org

O’Dwyer, L. M., Russell, M., \& Bebell, D. J. (2004). Identifying teacher, school and district characteristics associated with elementary teachers' use of technology: A multilevel perspective, Education Policy Analysis Archives, 12(48).

Papaioannou, P., \& Charalambous, K. (2011). Principals attitudes towards ICT and their perceptions about the factors that facilitate or inhibit ICT integration in primary schools of Cyprus. 10(3).

Professional Development (2011, June 29). Education Week. Retrieved from http://www.edweek.org/ew/issues/professinal-development/

Richardson, J. W, Bathon, J., Flora, K. L., \& Lewis, W D. (2012). NETS-A scholarship: a review of published literature. Journal of Research on Technology in Education, 45(2), (pp.131-151).

Richardson, J. W. \& McLeod, S. (2011). Technology leadership in native American schools. Journal of Research in Rural Education, 26(7).

Seferoglu, S. S. (2007). Primary school computer curriculum: A critical evaluation and problems faced during implementation. Eurasian Journal of Educational Research, 29, 99-111. 
Seferoglu, S. S. (2009). Ilkogretim Okullarinda Teknoloji Kullanimi ve Yoneticilerin Bakis Acilari. Akademik Bilisim2009, Harran Universitesi, Sanliurfa, 11-13 Subat 2009

Serhan, D. (2007). Schools principals' attitudes towards the use of technology: United Arab emirates technology workshop. 6(2), 5.

Shoffner, M. B. (2001). Models of instructional technology leadership in u. s. schools. Paper presented at the Society for Information Technology and Teacher Education International Conference, Orlando, FL.

Slowinski, J. (2003). Becoming a technologically savvy administrator. Teacher Librarian, 30(5), 25-29.

Smith, G. (2011). Instructional technology leadership ability of the school principal and effective use of technology in the classroom. Doctoral dissertation, Argosy University, Nashville, TN.

Thacker, C. (2007). Why use technology in education? Technology in Education. Retrieved from http://www.macinstruct.com/node/7

Townsend, T. (1999). The third millennium school: towards a quality education for all students. IARTV Seminar Series, February, 81, Jolimont, Victoria.

TSSA Collaborative (2001). Technology standards for school administrators. TSSA Draft (v4.0) Education Technology Cooperative. Retrieved from http://www.ncrtec.org/pd/tssa/tssa.pdf

Tweed, S. (2013). Technology implementation: teacher, age, experience, selfefficacy, and professional development as related to classroom technology integration. Doctoral dissertation, East Tennessee State University, Johnson City, TN.

Twomey, C. R., Shamburg, C., \& Zieger, L. B. (2006). Teachers as technology leaders. Eugene, OR: ISTE Publications.

Ury, G. (2003). Missouri public school principals' computer usage and conformity to technology standards. Dissertation Abstracts International, AAT 3091975. 
Naciye Güliz Uğur. Dr. Naciye Güliz Uğur is a faculty member of the Department of Management Information Systems at Sakarya University. Uğur received her Ph.D. in the field of MIS. She has more than five years of industry experience in management and teaches courses on information systems and system analysis and design. Her research interests include technology acceptance and behavioral aspects of emerging technologies. Uğur has also published articles in over 25 international conferences.

Contact Address: Sakarya University, Dept. of Management Information Systems, Sakarya, Turkey

E-mail: ngugur@sakarya.edu.tr

Tuğba Koç. Tuğba Koç is a research assistant in the Department of Management Information Systems at Sakarya University. Currently, she is a Ph.D. candidate in the field of MIS. Her interests include interdisciplinary research areas such as IT occupational subculture, educational technologies, and cultural issues about information systems. She has more than 15 international conference articles including AMCIS which is one of the state of art events.

Contact Address: Sakarya University, Dept. of Management Information Systems, Sakarya, Turkey

E-mail: tcekici@sakarya.edu.tr 